\title{
FOCUS ON HUMANITY
}

\section{A Century of Photography}

\author{
Archives of the International \\ Committee of the Red Cross \\ by Nicolas Bouvier, \\ Michèle Mercier, François Bugnion
}

The photographs contained in the archives of the International Committee of the Red Cross tell the story of people caught up in conflict, both victims and relief workers. They are the record of a century marked by deeds of extreme heroism as well as utmost infamy, bringing hope as well as despair.

This book reflects the evolution of international humanitarian law and role of visual images in humanitarian action.

Based on photo reports from the time of the Crimean War up to the Second World War, the first part of the book traces the history of the Geneva Conventions. The second part draws on mostly unpublished photographs to illustrate wars since 1950 - in Korea, Vietnam, Biafra, the Middle East, Rwanda, Bosnia-Herzegovina, and many other theatres of conflict.

Whatever the changes in ways of making war, human suffering and the age-old gesture of compassion towards one's fellows remain the same.

$24 \times 30 \mathrm{~cm}, 150$ pages, 130 illustrations, hardbound with illustrated jacket - Skira, 1995 (in English and in French)

Price per unit: SFR 68.- (postage not included)

SFR 48. - for National Red Cross and Red Crescent Societies, members of the Association of Former ICRC Delegates and ICRC staff

Orders to be sent to:

INTERNATIONAL COMMITTEE OF THE RED CROSS

Public Information Division

19, avenue de la Paix, CH-1202 Geneva

Tel. (++4122) 7302422 or 73024 09, Fax (++4122) 7348280 


\section{ARTICLES SUBMITTED FOR PUBLICATION IN THE INTERNATIONAL REVIEW OF THE RED CROSS}

The International Review of the Red Cross invites readers to submit articles relating to the various humanitarian concerns of the International Red Cross and Red Crescent Movement. These will be considered for publication on the basis of merit and relevance to the topics to be covered during the year.

Manuscripts will be accepted in English, French, Spanish, Arabic or Russian.

Texts should be typed, double-spaced, and no longer than 20 pages (or 4,000 words). Please send diskettes if possible (Wordperfect 5.1 preferred).

Footnotes (no more than 30) should be numbered superscript in the main text. They should be typed, double-spaced, and grouped at the end of the article.

Bibliographical references should include at least the following details: (a) for books, the author's initials and surname (in that order), book title (underlined), place of publications, publishers and year of publication (in that order), and page number(s) referred to (p. or pp.); (b) for articles, the author's initials and surname, article title in inverted commas, title of periodical (underlined), place of publication, periodical date, volume and issue number, and page number(s) referred to (p. or pp.). The titles of articles, books and periodicals should be given in the original language of publication.

The Review reserves the right to edit all articles before publication.

Unpublished manuscripts will not be returned.

Published works sent to the editor will be mentioned in the list of publications received and, if considered appropriate, reviewed.

Manuscripts, correspondence and requests for permission to reproduce texts appearing in the Review should be addressed to the editor.

Articles, studies, and other signed texts from non-ICRC sources published in the Review reflect the views of the author alone and not necessarily those of the ICRC. 
The International Review of the Red Cross is the official publication of the International Committee of the Red Cross. It was first published in 1869 under the title "Bulletin international des Sociétés de secours aux militaires blessés", and then "Bulletin international des Sociétés de la Croix-Rouge".

The International Review of the Red Cross is a forum for reflection and comment and serves as a reference work on the mission and guiding principles of the International Red Cross and Red Crescent Movement. It is also a specialized journal in the field of international humanitarian law and other aspects of humanitarian endeavour.

As a chronicle of the international activities of the Movement and a record of events, the International Review of the Red Cross is a constant source of information and maintains a link between the components of the International Red Cross and Red Crescent Movement.

The International Review of the Red Cross is published every two months, in five main editions:

French: REVUE INTERNATIONALE DE LA CROIX-ROUGE (since October 1869)

English: INTERNATIONAL REVIEW OF THE RED CROSS (since April 1961)

Spanish: REVISTA INTERNACIONAL DE LA CRUZ ROJA (since January 1976)

Arabic: البجلة الدولية للصليب الأحمر (since May-June 1988)

Russian: МЕЖДУНАРОДНЫЙ ЖУРНАЛ КРАСНОго КРЕСТА (since November-December 1994)

Selected articles from the main editions have also been published in German under the title Auszüge since January 1950.

EDITOR: Hans-Peter Gasser, Doctor of Laws, editor-in-chief

ADDRESS: International Review of the Red Cross

19, avenue de la Paix

1202 Geneva, Switzerland

SUBSCRIPTIONS: one year, 30 Swiss francs or US\$ 18

single copy, 5 Swiss francs

Postal cheque account No. 12 - 1767-1 Geneva

Bank account No. 129.986.0, Swiss Bank Corporation, Geneva

The International Committee of the Red Cross (ICRC) and the International Federation of Red Cross and Red Crescent Societies, together with the National Red Cross and Red Crescent Societies, form the International Red Cross and Red Crescent Movement.

The $I C R C$, which gave rise to the Movement, is an independent humanitarian institution. As a neutral intermediary in the event of armed conflict or unrest it endeavours, on its own initiative or on the basis of the Geneva Conventions, to bring protection and assistance to the victims of international and non-international armed conflict and internal disturbances and tension. 


\title{
INTERNATIONAL REVIEW
}

\author{
Special
}

\section{6th INTERNATIONAL CONFERENCE OF THE RED CROSS AND RED CRESCENT}

(Geneva, 3-7 December 1995) 